\title{
Nottingham University and British American Tobacco
}

\author{
J Britton, A Knox
}

Like many employees of Nottingham University we were both surprised and dismayed to learn in early December ${ }^{1}$ that the University had decided to accept funding from British American Tobacco to establish an International Centre for Corporate Social Responsibility. Apparently the major focus of the International Centre will be the developing world, from which it is proposed to appoint a visiting Professor and to provide competitive scholarships for students from developing nations to study the "environmental responsibilities of multinational companies". 1

We believe that this funding has been awarded in an attempt to gain respectability and credibility for an industry that is fundamentally unethical ${ }^{2}{ }^{3}$ at a time when the industry is having to expand into the developing world to replace markets currently being lost in more affluent countries. ${ }^{2}$ A comprehensive discussion of the ethics of this decision and other comments relevant to the company

involved have been presented elsewhere in the public domain ${ }^{34}$ and we do not propose to add to these comments here. However, we do believe that accepting money from the tobacco industry degrades the reputation of our University and undermines the work of all with a commitment to the teaching of medicine and the promotion of public health.

JOHN BRITTON ALAN KNOX

Executive Editors

1 Tobacco firm backs corporate ethics professorship. Sunday Times, 3 December 2000 (http:www.sunday-times.co.uk/news/pages/sti/2000/12/ 03/stibusnws01011.html)

2 Britton J. Tobacco: the epidemic we could all avoid. Thorax 1997;52:10212 .

3 Chapman S. The ethics of the cash register: taking tobacco research dollars. Tobacco Control 2001;10:1-2.

4 Bates C. University of Nottingham takes $£ 3.8 \mathrm{~m}$ from BAT for a Centre for Corporate Social Responsibility (http://www.ash.org.uk/html/conduct/ $\mathrm{html} /$ nottingham.html)

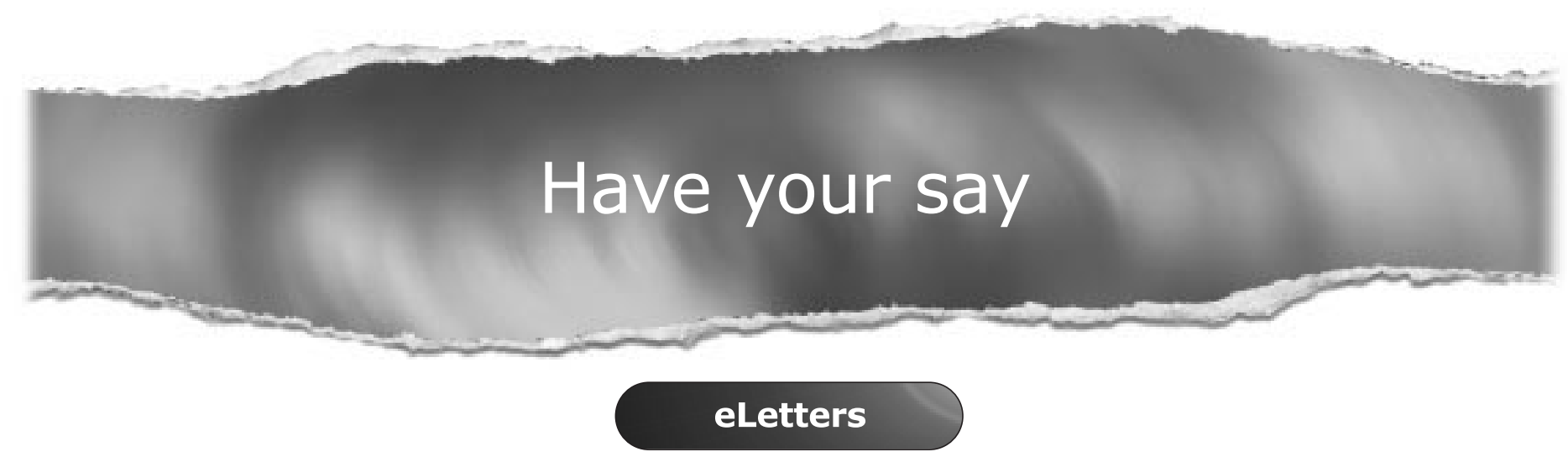

If you wish to comment on any article published in Thorax you can send an eLetter using the eLetters link at the beginning of each article. Your response will be posted on Thorax online within a few days of receipt (subject to editorial screening).

\section{www.thoraxjnl.com}

